\title{
Fossa navicularis in a pediatric patient: anatomical skull base variant with clinical implications
}

\author{
Andrew F. Alalade, MBBS, FRCS(SN), ${ }^{1,6}$ Giovanni Briganti, BS, ${ }^{2}$ Jo-Lyn Mckenzie, MBBS, ${ }^{3}$ \\ Mitesh Gandhi, MBBS, MRCP, FRCR, FRANCZR, ${ }^{4,5}$ Damian Amato, MBBS, MSurg, FRACS, ${ }^{6}$ \\ Benedict J. Panizza, MBBS, MBA, FRACS, ${ }^{6}$ and James Bowman, BDSc, MBBS, FRACS ${ }^{3,6}$

\begin{abstract}
1Victor Horsley Department of Neurosurgery, National Hospital for Neurology and Neurosurgery, London, United Kingdom; ${ }^{2}$ Faculty of Medicine, Université libre de Bruxelles, Brussels, Belgium; ${ }^{3}$ Department of Otorhinolaryngology, Lady Cilento Children's Hospital, Brisbane; ${ }^{4}$ Department of Radiology, Princess Alexandra Hospital, Brisbane; ${ }^{5}$ Queensland X-Ray, Brisbane; and ${ }^{6}$ Queensland Skull Base Unit, Princess Alexandra Hospital, Brisbane, Australia
\end{abstract}

\begin{abstract}
The fossa navicularis is an anatomical variant of the skull base thought to be a rare finding. It represents a bony depression in the skull base. The authors here report the case of a fossa navicularis magna in a 9-year-old female who had been treated for recurrent episodes of meningitis.

A literature review was also done to highlight the unique features and clinical importance of this distinctive radiological skull base finding. The literature search covered papers from the 19th century up to 2018. Earlier authors described "fossa navicularis" as a very rare skull base finding. So far, only three cases of fossa navicularis with associated clival or intracranial infection have been reported in the literature. This is the fourth reported case, and the defect was closed endoscopically via a transnasal route. This morphological skull base anomaly should be considered in the differential diagnoses for an unexplained skull base infective pathology.
\end{abstract}

Skull base surgeons should be aware of the existence of the fossa navicularis because of its clinical importance in rendering a prompt diagnosis and appropriate treatment.

https://thejns.org/doi/abs/10.3171/2018.5.PEDS18157

KEYWORDS skull base; clivus; anatomy; anatomical variant; bone defect; basiocciput; infection; congenital

$\mathrm{T}$ HE skull base is a complex osseous structure forming the floor of the calvaria. The anatomy of the skull base is often evaluated using CT and MRI in order to detect morphological abnormalities and pathological lesions. ${ }^{8}$ The basiocciput is the wedge-like segment of the occiput that lies anterior to the foramen magnum and joins the body of the sphenoid bone. There are anatomical variants of the basiocciput, and even though they are largely uncommon, their presence has significant diagnostic and clinical implications. One of these variants is the "fossa navicularis magna," a notch-like defect in the clivus (Fig. 1) at the embryological synchondrosis fusion-junction of the body of the sphenoid bone with the basilar part of the occipital bone. ${ }^{2}$ It is suggested that a patent fossa navicularis magna could be a conduit for infection from the pharynx to the calvarial and intracranial structures.

We reviewed scientific databases-PubMed Central, EMBASE, Google Scholar, Scopus, Cochrane, and Science Research-for the years 1860-2018 using the key words "fossa navicularis," "canalis basilaris medianus," and "pharyngeal fossa." We identified the papers in which these terms were used and described the distinctive features and clinical relevance of this distinctive skull base radiological finding. This will be the fourth case reported in the literature, and the defect was closed endoscopically via a transnasal route.

\section{Case Report}

History and Presentation

A 9-year-old female was referred to our hospital. She initially presented with clinical signs suggesting meningitis and subsequently developed an isolated abducens nerve palsy that resolved after antibiotic therapy (co-amoxiclav). Clinical features included bitemporal throbbing headaches, left retroorbital pain, photosensitivity, neck stiffness, and fever (temperature $40.3^{\circ} \mathrm{C}$ ). Her white cell count was 47 $\times 10^{9} / \mathrm{L}$, platelet count was $557 \times 10^{9} / \mathrm{L}$, and C-reactive

ABBREVIATIONS CBM = canalis basilaris medianus.

SUBMITTED March 18, 2018. ACCEPTED May 10, 2018.

INCLUDE WHEN CITING Published online July 27, 2018; DOI: 10.3171/2018.5.PEDS18157. 


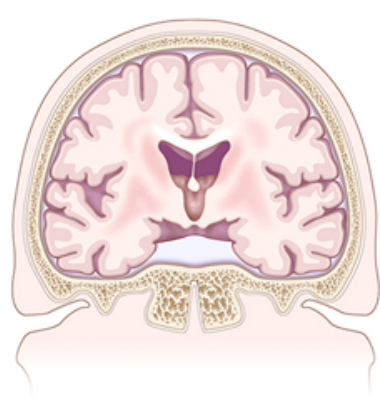

A

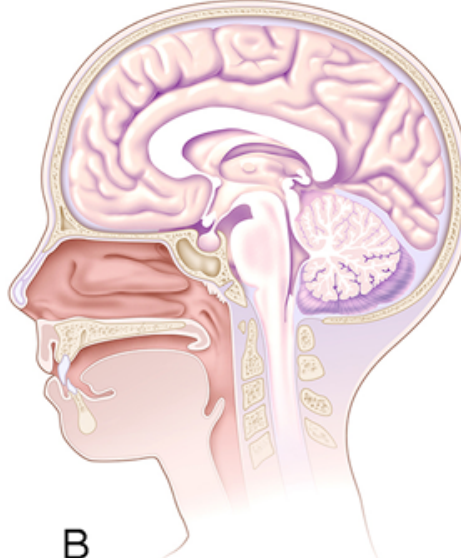

B

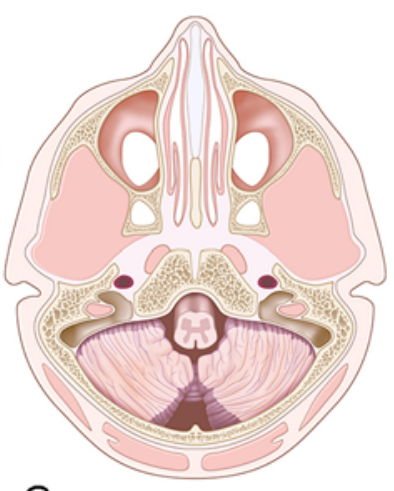

C

FIG. 1. Illustration showing the fossa navicularis within the clivus in three axes. Note the notch-like defect posterior to the nasopharyngeal wall. A: The fossa navicularis in a coronal view of the clivus. B: Fossa navicularis in the sagittal view. C: Notch-like defect (fossa navicularis) shown in the axial view. Copyright Holt Illustration. Published with permission. Figure is available in color online only.

protein level was $20 \mathrm{mg} / \mathrm{L}$. Nine months later, she again presented to us with headache and cranial nerve (III and VI) palsies. No other neurological deficits were noted on examination. Fundal examination was normal. Her parents reported a previous medical history of sinusitis and recurrent meningitis. There were no symptoms suggestive of pituitary dysfunction. She was started on intravenous ceftriaxone. The cranial nerve palsies resolved within 3 weeks, and no other neurological deficit was noted during review.

Magnetic resonance imaging of the brain demonstrated enhancement of the basal meninges, particularly in the left perimesencephalic region. Fluid was also reported in the ethmoid and sphenoid sinuses. Lumbar puncture CSF showed no organisms. The CSF glucose was $3 \mathrm{mmol} / \mathrm{L}$, and the CSF protein level was $57 \mathrm{mg} / \mathrm{dl}$. There was no organism growth on blood cultures.

Repeat imaging-CT (Fig. 2) and MRI (Fig. 3) -was done following yet another admission with meningitic features and was reviewed by our multidisciplinary skull base team. A fossa navicularis magna was noted within

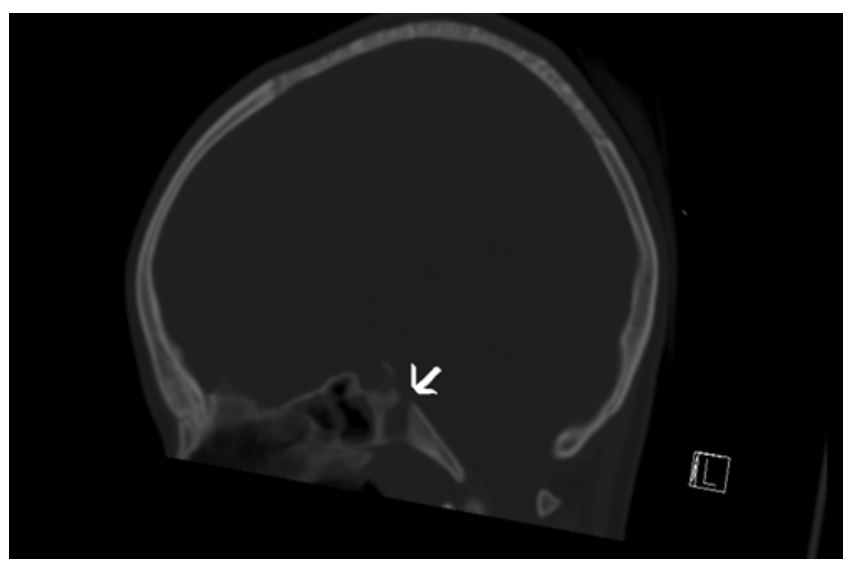

FIG. 2. Sagittal bone window CT scan demonstrating an aperture (fossa navicularis, arrow) through the clivus. the clivus with enhancement noted in the surrounding basiocciput. A small subperiosteal collection was also noted in the nasopharynx. Transient clinical improvement and radiological resolution was initially noted following antibiotic treatment for skull base osteomyelitis-intravenous ceftriaxone for 6 weeks (with intravenous metronidazole in the 1st week). This was later followed by a 6 -week course of oral co-amoxiclav.

\section{Operation and Postoperative Course}

Because of further repeated episodes of infection and inflammation, the patient underwent endonasal endoscopic surgical removal of the infected clival tissue and fossa navicularis. Via a posterior septectomy approach, a wide sphenoidotomy was performed, and the floor of the sphenoid sinus was drilled down to expose the fossa navicularis and remove the diseased bone. Intraoperatively, a tract was apparent within the soft infected bone (Fig. 4). A concurrent adenoidectomy was performed to remove any reservoir of infective pharyngeal tissue. No obvious dural breach was noted.

Tissue specimens were obtained intraoperatively, and histological analysis demonstrated gliotic tissue of the macroscopically apparent tract within soft clival bone. No lymphoid tissue was seen, and the specimen primarily showed infiltrative inflammatory cells within the infected bone. Biopsy of the nasopharyngeal mucosa revealed normal mucosa, which cultured respiratory flora. Culture of the bone of the clivus did not yield an organism. The bone was friable and very vascular, but no purulent material was noted. Recovery was uneventful and there were no complications. The procedure was very well tolerated, and in the absence of antibiotic therapy, there had been no recurrence of symptoms at the 6-month follow-up review.

\section{Discussion}

\section{Description and Nomenclature}

The fossa navicularis is a notch-like defect located in 

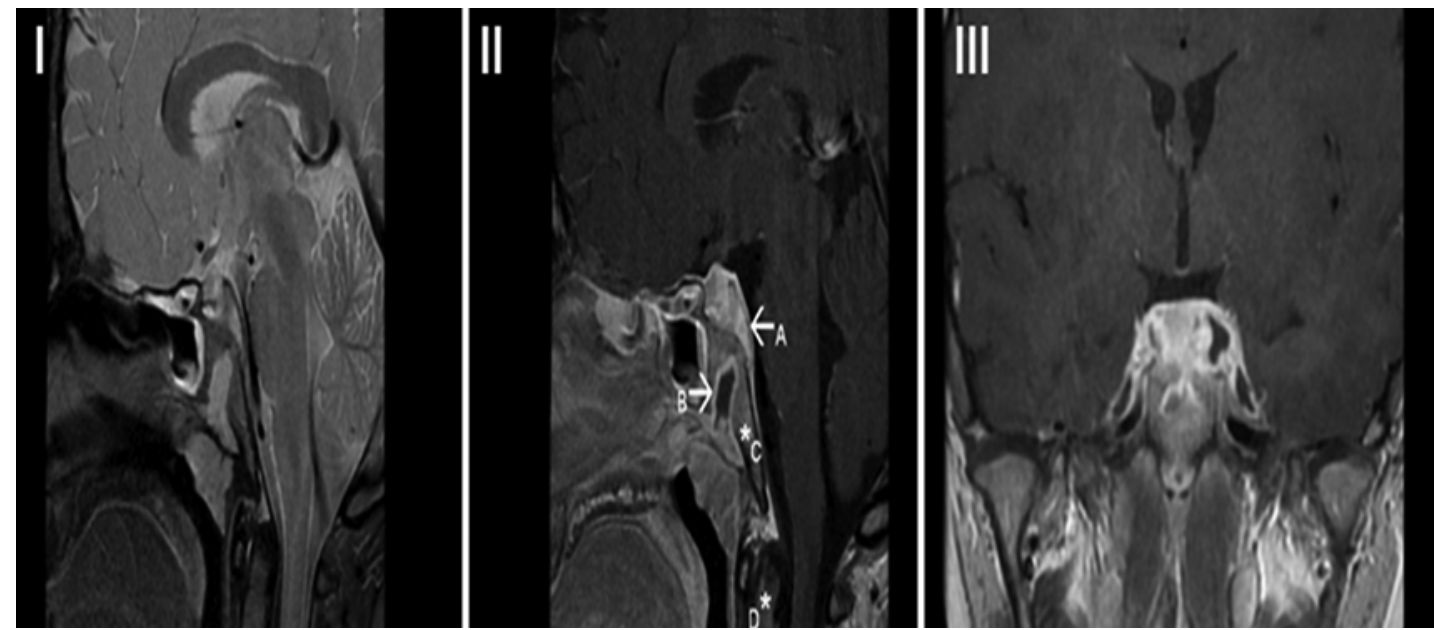

FIG. 3. I: Sagittal fat-saturated Gd-enhanced T1-weighted MR image demonstrating fossa navicularis magna within the clivus. II: Sagittal T2-weighted MR image showing dural thickening $(A)$ posterior to the clivus with associated enhancement. There is a rim-enhancing collection/abscess (B) within the canal in the body of the clivus. Enhancement of the marrow of the clivus (C) is greater than in the marrow elsewhere, e.g., of the odontoid process (D), in keeping with an associated osteomyelitis. III: Coronal MR image demonstrating involvement of the cavernous sinus.

the exocranial portion of the clivus. Over the years, various authors have suggested a diverse number of names and/or descriptive terminologies: "fossa navicularis magna," "medial basal fossa," "fossa pharyngea," "large pharyngeal fossa," "canalis basilaris medianus" (CBM), and "keyhole defect." ${ }^{\prime 7}$ It has been regarded as an uncommon skull base foramen. Ginat et al. ${ }^{6}$ observed that even though several inconstant skull base foramina could be radiologically diagnosed as incidental findings, there could be significant clinical importance to such findings because of related anomalies and medical implications. Apart from the fossa navicularis, some of the other skull base foramina include the meningo-orbital foramen, palatovaginal canal, persistent craniopharyngeal canal foramen of Vesalius, canalicus innominatus, and CBM.

Currarino ${ }^{5}$ posited that the fossa navicularis is one of the six subtypes of the CBM and an incomplete form of CBM. Perna ${ }^{12}$ considered the fossa navicularis as a representation of the cephalic end of the CBM. Beltramello et al. ${ }^{2}$ offered a different viewpoint and described CBM as a persistent form of the chordal canal, and thus a disparate anatomical variant. However, Prabhu et al..$^{13}$ consider the fossa navicularis and the CBM as similar anatomical findings. There have also been developmental links between the Thornwaldt (or Tornwaldt) cyst and fossa navicularis. ${ }^{3,5,5,16}$

\section{Embryological Origin}

Two general theories have been suggested regarding the embryological origin of the fossa navicularis-a vascular origin and a notochordal origin. The vascular theory suggests that the notch-like defect is caused by the persistence and enlargement of several emissary veins passing through the clivus and therefore forms a bony aperture similar to the venous foramina in the vertebral bodies. ${ }^{13}$ Based on information about the embryological formation of the skull base in the fetal period, ${ }^{8}$ the vascular theory is plausible since the clivus would then be formed around its own emissary veins, leaving a passage in its center. This theory is supported by Prabhu et al., ${ }^{13}$ who suggested that the remnant vessels and lymphatics passing through the clivus give rise to the fossa navicularis.

The notochordal theory was first suggested by Perna, ${ }^{12}$ who reported that the fossa navicularis may be a remnant of the notochordal canal. The notochordal theory was supported by Beltramello et al., ${ }^{2}$ who considered that a remnant of the notochord in the roof of the pharynx prevents complete ossification of the clivus, therefore giving rise to the fossa navicularis. Thus, the remnant may represent a tract for infection to travel from the pharyngeal mucosa to the skull base and central nervous system.

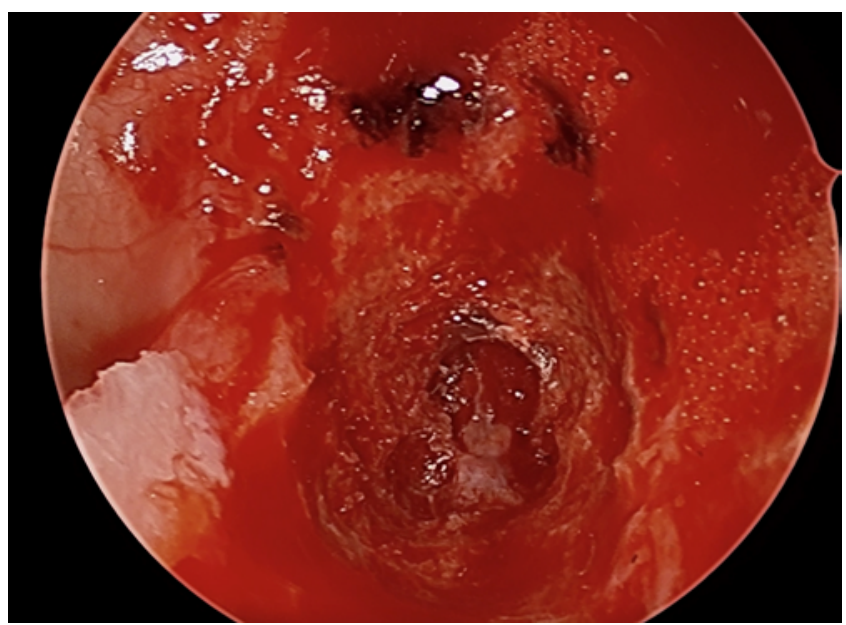

FIG. 4. Photograph obtained via an endonasal endoscopic approach, showing the fossa navicularis defect on the anterior wall of the clivus. Figure is available in color online only. 
TABLE 1. Literature summary of cases with clinical presentation, radiographic findings, treatment, and outcomes

\begin{tabular}{|c|c|c|c|c|}
\hline Parameter & Prabhu et al., 2009 & Segal et al., 2013 & Benadjaoud et al., 2017 & Alalade et al., 2018 \\
\hline Case No. & 1 & 2 & 3 & Present case \\
\hline Age in yrs & 5 & 12 & 7 & 9 \\
\hline Sex & $\mathrm{F}$ & $\mathrm{F}$ & M & M \\
\hline $\begin{array}{l}\text { Clinical pre- } \\
\text { sentation }\end{array}$ & $\begin{array}{l}\text { Fever, reduced oral intake, neck } \\
\text { stiffness, bilat cervical lymph- } \\
\text { adenopathy }\end{array}$ & $\begin{array}{l}\text { Fever, HA, neck stiffness, Kernig's \& } \\
\text { Brudzinski's signs, It strabismus, } \\
\text { altered consciousness, opisthotonus }\end{array}$ & HAs, fever, torticollis & $\begin{array}{l}\text { HAs, fever, photosensi- } \\
\text { tivity, neck stiffness, } \\
\text { cranial nerve palsies }\end{array}$ \\
\hline $\begin{array}{l}\text { Radiographic } \\
\text { findings }\end{array}$ & $\begin{array}{l}\text { XR: thickening of prevertebral } \\
\text { soft tissues; CT: large retro- } \\
\text { pharyngeal abscess w/ notch- } \\
\text { like clival defect w/ associated } \\
\text { osteolysis \& cortical destruc- } \\
\text { tion; MRI: abnormal clival } \\
\text { enhancement w/ collections w/ } \\
\text { in longus colli bilaterally }\end{array}$ & $\begin{array}{l}\text { CT: small fluid collection in nasophar- } \\
\text { ynx just in front of clivus \& a bony } \\
\text { notch-like round defect; MRI: soft } \\
\text { tissue swelling in nasopharyngeal \& } \\
\text { suboccipital areas; It internal jugular } \\
\text { vein thrombus; connection btwn } \\
\text { nasopharynx \& skull base }\end{array}$ & $\begin{array}{l}\text { CT: fossa navicularis magna } \\
\text { in basiocciput; MRI: clival } \\
\text { osteomyelitis w/ associated } \\
\text { retropharyngeal abscess } \\
\text { \& C1-2 epidural enhance- } \\
\text { ment }\end{array}$ & $\begin{array}{l}\text { CT: fossa navicularis } \\
\text { magna through clivus; } \\
\text { MRI: fossa navicularis } \\
\text { w/in clivus; rim- } \\
\text { enhancing collection } \\
\text { w/in canal; associated } \\
\text { clival osteomyelitis }\end{array}$ \\
\hline $\begin{array}{l}\text { Implicated } \\
\text { organisms }\end{array}$ & Group A Streptococcus & NA & $\begin{array}{l}\text { Streptococcus intermedius, } \\
\text { Fusobacterium spp. }\end{array}$ & NA \\
\hline Treatment & $\begin{array}{l}\text { Medical: initially IV ceftriaxone } \\
\text { for } 4 \text { wks, followed by } 4 \text { wks } \\
\text { oral amoxicillin; surgical: } \\
\text { transoral incision \& drainage } \\
\text { of retropharyngeal abscess }\end{array}$ & Medical: antibiotics ${ }^{*}$ anticoagulants ${ }^{*}$ & $\begin{array}{l}\text { Medical: initially IV cefotaxime, } \\
\text { metronidazole, gentamicin } \\
\text { for } 1 \text { st } 7 \text { days; IV co-amox- } \\
\text { iclav after definitive culture } \\
\text { results, followed by } 3 \text { mos } \\
\text { oral pristinamycin; surgical: } \\
\text { transnasal aspiration of } \\
\text { retropharyngeal abscess }\end{array}$ & $\begin{array}{l}\text { Medical: initially IV } \\
\text { ceftriaxone for } 6 \text { wks } \\
\text { (additional IV metro- } \\
\text { nidazole for } 1 \text { st wk), } \\
\text { followed by } 6 \text { wks oral } \\
\text { amoxicillin; surgical: } \\
\text { endonasal endoscopic } \\
\text { repair of defect }\end{array}$ \\
\hline Outcome & Good, no sequelae & $\begin{array}{l}\text { Resolution of strabismus \& partial reso- } \\
\text { lution of venous sinus thrombosis }\end{array}$ & Good, no sequelae & Good, no sequelae \\
\hline
\end{tabular}

$\mathrm{HA}=$ headache; IV = intravenous; $\mathrm{NA}=$ not applicable; $\mathrm{XR}$ = radiography.

${ }^{*}$ Name not provided.

\section{Epidemiology}

The reported incidence of the fossa navicularis in the anatomical literature is $0.9 \%-5.3 \%$, with measurements ranging from 1.1 to $5.5 \mathrm{~mm}$ in depth and $1.5-8 \mathrm{~mm}$ in width. ${ }^{16}$

The finding was first reported in the early 19th century-Rossi reported it in 1.5\% of the 3712 dried skulls he studied, Romiti reported it in $0.9 \%$ of 990 skulls, ${ }^{14}$ and Rizzo reported it in $2.1 \%$ of 335 skulls. ${ }^{2}$ More recently, Cankal et al. ${ }^{4}$ looked at 492 dry skulls and the CT images of 525 patients to determine the incidence of fossa navicularis. They found the variant in 5.3\% of the dry skulls examined $(2.4 \%$ were less than $2 \mathrm{~mm}$ deep, and $2.9 \%$ were deeper than $2 \mathrm{~mm}$ ). From the CT evaluation, they found that $3.0 \%$ of the patients had a fossa navicularis. As the CT sections were $2 \mathrm{~mm}$ (and would not highlight defects smaller than that), the authors suggested that the incidence of fossa navicularis was similar in their population and more frequent than previous studies had suggested.

As high-resolution skull base imaging is increasingly available, we propose that a detailed evaluation of the skull base is useful in determining the real incidence of this anatomical variant and will aid prompt diagnosis of the etiological factor in relevant infective scenarios. It is highly likely that the incidence may be higher than previously reported.

\section{Anatomy}

The fossa navicularis is a small round medio-sagittal bony aperture in the anterior surface of the clivus, more specifically, in the basilar part of the occipital bone. It lies close to the nasopharynx and the sphenoidal sinuses. ${ }^{4}$ It is superior to the pharyngeal tubercle and is parallel to the carotid canals. ${ }^{2}$ The fossa navicularis tends to be located at the exit site of the notochord in early fetal life at the base of the anterior basiocciput. ${ }^{5}$

\section{Histology}

Beltramello et al. ${ }^{2}$ reported in their case study that the fossa navicularis was filled by lymphoid tissue of the pharyngeal tonsil. Their patient was diagnosed with a prominent fossa navicularis following evaluation for sinusitis. This finding was supported by Prabhu et al. ${ }^{13}$ who identified lymphoid tissue from the pharyngeal tonsil around the fossa navicularis. In a more recent study, Sheikh et al. ${ }^{16}$ found the overlying tissue to be composed of loose connective tissue with a mixture of collagen, elastic fibers, and vascular matrix. They reported no glandular, lymphoid, or notochordal tissue in the histologically analyzed tissues. Our histopathological assessment revealed gliotic tissue within the visible tract, which represents a new finding. 


\section{Clinical Importance, Diagnosis, and Treatment}

The fossa navicularis has been considered a benign anatomical variation of the clivus until recently; cases reported in the literature are shown in Table 1. Other anatomical variants in the basiocciput do not seem to be associated with a similar risk of infection. Even most cases of fossa navicularis do not seem to be associated with intracranial infection. Syed et al. ${ }^{17}$ reported 4 cases of fossa navicularis diagnosed incidentally. Longer follow-ups in these cases would be necessary for the assessment of recurrent infection, and surgical exploration should be considered as the optimal mode of treatment in these cases.

The MRI features of bone marrow in the clivus have been seen to vary with age.,10,11 In childhood, the bone marrow is rich in hematopoietic tissue and the clivus is homogeneously hypointense. This is referred to as "stage I" clivus bone marrow as opposed to stage II (intermediate stage with fatty infiltration of the marrow and the clivus has a heterogeneous appearance) or stage III (hypoactive marrow with a homogeneous hypoactive clivus). Olcu et al..$^{10}$ found in their study that the stage III features were not noted in the age group of 0-9 years. In cases in which unexpected MRI clival changes are noted, as was the case with our patient, there is most likely an underlying pathology.

The synchondroses at the skull base are important for craniofacial development, and the spheno-occipital synchondrosis usually completely fuses at 18 years. ${ }^{1}$ However, this joint is different from the fossa navicularis as the fusion begins superiorly and progresses inferiorly, through the five stages described by Bassed et al. ${ }^{1}$ In stages II and III, when partially fused, it is typically visible as a linear partition between the sphenoid and occiput rather than the notch-like defect appearance of the fossa navicularis.

\section{Conclusions}

The fossa navicularis is a defect in the ossification of the exocranial clivus. Physicians should be aware of its existence because of its role in intracranial infections. As high-resolution CT and MRI become increasingly accessible, we propose that careful scrutiny of the skull base will be beneficial for determining the real incidence of this anatomical variant and will aid prompt diagnosis of the etiological factor in relevant infective scenarios. Our review suggests that the incidence may be higher than previously reported.

\section{References}

1. Bassed RB, Briggs C, Drummer OH: Analysis of time of closure of the spheno-occipital synchondrosis using computed tomography. Forensic Sci Int 200:161-164, 2010

2. Beltramello A, Puppini G, El-Dalati G, Girelli M, Cerini $\mathrm{R}$, Sbarbati A, et al: Fossa navicularis magna. AJNR Am J Neuroradiol 19:1796-1798, 1998

3. Benadjaoud Y, Klopp-Dutote N, Choquet M, Brunel E, Guiheneuf R, Page C: A case of acute clival osteomyelitis in a 7-year-old boy secondary to infection of a Thornwaldt cyst. Int J Pediatr Otorhinolaryngol 95:87-90, 2017
4. Cankal F, Ugur HC, Tekdemir I, Elhan A, Karahan T, Sevim A: Fossa navicularis: anatomic variation at the skull base. Clin Anat 17:118-122, 2004

5. Currarino G: Canalis basilaris medianus and related defects of the basiocciput. AJNR Am J Neuroradiol 9:208-211, 1988

6. Ginat DT, Ellika SK, Corrigan J: Multi-detector-row computed tomography imaging of variant skull base foramina. J Comput Assist Tomogr 37:481-485, 2013

7. Kimura F, Kim KS, Friedman H, Russell EJ, Breit R: MR imaging of the normal and abnormal clivus. AJR Am J Roentgenol 155:1285-1291, 1990

8. Kunimatsu A, Kunimatsu N: Skull base tumors and tumorlike lesions: a pictorial review. Pol J Radiol 82:398-409, 2017

9. Miyahara H, Matsunaga T: Tornwaldt's disease. Acta Otolaryngol Suppl 517:36-39, 1994

10. Olcu E, Arslan M, Sabanciogullari V, Salk I: Magnetic resonance imaging of the clivus and its age-related changes in the bone marrow. Iran J Radiol 8:224-229, 2011

11. Oyar O, Gövsa F, Sener RN, Kayalioglu G: Assessment of normal clivus related to age with magnetic resonance imaging. Surg Radiol Anat 18:47-49, 1996

12. Perna G: Sul canale basilare mediano e sul significato della fossetta faringea dell'osso occipitale. Anat Anz 28:379-392, 1906

13. Prabhu SP, Zinkus T, Cheng AG, Rahbar R: Clival osteomyelitis resulting from spread of infection through the fossa navicularis magna in a child. Pediatr Radiol 39:995-998, 2009

14. Romiti G: Canale basilare mediano dell'osso occipitale. Verb Soc Tosc Sci Nat Pisa:219, 1881

15. Segal N, Atamne E, Shelef I, Zamir S, Landau D: Intracranial infection caused by spreading through the fossa naviclaris magna-a case report and review of the literature. Int J Pediatr Otorhinolaryngol 77:1919-1921, 2013

16. Sheikh S, Iwanaga J, Rostad S, Rustagi T, Oskouian RJ, Tubbs RS: The first histological analysis of the tissues lining the fossa navicularis: insights to its etiology. Cureus 9:e1299, 2017

17. Syed AZ, Mupparapu M: Fossa navicularis magna detection on cone-beam computed tomography. Imaging Sci Dent 46:47-51, 2016

\section{Disclosures}

The authors report no conflict of interest concerning the materials or methods used in this study or the findings specified in this paper.

\section{Author Contributions}

Conception and design: Alalade, Briganti. Acquisition of data: Alalade, Briganti, McKenzie. Analysis and interpretation of data: Alalade, Briganti, McKenzie, Gandhi. Drafting the article: Alalade, Briganti, McKenzie. Critically revising the article: Alalade, Gandhi, Amato, Panizza, Bowman. Reviewed submitted version of manuscript: Alalade, Amato, Panizza, Bowman. Approved the final version of the manuscript on behalf of all authors: Alalade. Administrative/technical/material support: Alalade.

\section{Correspondence}

Andrew F. Alalade: Princess Alexandra Hospital, Brisbane, Australia. andrew.alalade@nhs.net. 